\title{
Gangjinia marincola gen. nov., sp. nov., a marine bacterium of the family Flavobacteriaceae
}

Correspondence Hyung-Yeel Kahng kahng@sunchon.ac.kr

\section{Dong-Heon Lee, ${ }^{1}$ Sung-Ran Moon, ${ }^{1}$ Young-Hyun Park, ${ }^{1}$ Young Sun Lee, ${ }^{2}$ Jae Sung Jung, ${ }^{2}$ Jung Ho Kim, ${ }^{3}{ }{ }^{1}$ oon $\mathrm{Kim}^{3}$ and Hyung-Yeel Kahng ${ }^{1}$}

\author{
${ }^{1}$ Department of Environmental Education, Sunchon National University, Sunchon 540-742, \\ Republic of Korea \\ ${ }^{2}$ Department of Biology, Sunchon National University, Sunchon 540-742, Republic of Korea \\ ${ }^{3}$ Department of Biological Environment, Sunchon National University, Sunchon 540-742, Republic \\ of Korea
}

\begin{abstract}
A novel strictly aerobic, orange-pigmented, Gram-stain-negative bacterium, designated strain GJ16 ${ }^{\top}$, was isolated from coastal seawater of Gangjin Bay, the southernmost part of the Korean peninsula, and subjected to a polyphasic taxonomic study. It grew optimally at $25-30{ }^{\circ} \mathrm{C}$, at $\mathrm{pH}$ 7.0-8.0 and in the presence of $3 \% \mathrm{NaCl}$. Comparative 16S rRNA gene sequence analysis revealed that strain GJ16 ${ }^{\top}$ formed a distinct lineage within the family Flavobacteriaceae and shared less than $91.2 \% 16 \mathrm{~S}$ rRNA gene sequence similarity with members of the genera Leptobacterium, Zhouia, Winogradskyella, Dokdonia and Krokinobacter. The predominant cellular fatty acids were iso- $\mathrm{C}_{15: 0}(40.2 \%)$, iso- $\mathrm{C}_{15: 1} \mathrm{G}(12.8 \%)$, iso- $\mathrm{C}_{17: 0} 3-\mathrm{OH}(11.2 \%)$ and $\mathrm{C}_{15: 0}(6.6 \%)$. The $\mathrm{G}+\mathrm{C}$ content of the genomic DNA was $39.4 \mathrm{~mol} \%$ and the major respiratory isoprenoid quinone was MK-6. On the basis of phenotypic and genotypic data, strain GJ16 ${ }^{\top}$ represents a novel species in a new genus in the family Flavobacteriaceae, for which the name Gangjinia marincola gen. nov., sp. nov. is proposed; the type strain is GJ16 ${ }^{\top}\left(=\mathrm{KCTC}_{2049} 2649^{\top}=\mathrm{JCM} 16082^{\top}\right)$.
\end{abstract}

The family Flavobacteriaceae (Bernardet et al., 2002) is one of the major branches of the phylum 'Bacteroidetes' and contains 90 genera with validly published names (http:// www.bacterio.cict.fr/) at the time of writing. Members of the family occur in a variety of soil, freshwater and marine environments (Bernardet \& Nakagawa, 2006), with those of marine origin forming a distinct clade in the phylogenetic tree (Bowman, 2006). A novel Gram-stain-negative bacterium that produced orange pigments was isolated from seawater of Gangjin Bay and investigated using a polyphasic approach. This organism is described below as a member of a novel species in a new genus within the family Flavobacteriaceae, for which the name Gangjinia marincola gen. nov., sp. nov. is proposed.

Strain $\mathrm{GJ} 16^{\mathrm{T}}$ was isolated from seawater collected from Gangjin Bay ( $\left.34^{\circ} 27^{\prime} 44^{\prime \prime} \mathrm{N} 126^{\circ} 47^{\prime} 20^{\prime \prime} \mathrm{E}\right)$, Korea, by using a standard dilution plating technique on marine agar 2216 (MA; Difco) at $28{ }^{\circ} \mathrm{C}$ for 5 days. Subcultivation was performed routinely on MA at $30{ }^{\circ} \mathrm{C}$ for 3 days under aerobic conditions and the strain was preserved at $-80{ }^{\circ} \mathrm{C}$

\footnotetext{
The GenBank/EMBL/DDBJ accession number for the 16S rRNA gene sequence of strain GJ16 ${ }^{\top}$ is FJ463655.

A supplementary figure is available with the online version of this paper.
}

in marine broth (MB; Difco) supplemented with $20 \%$ glycerol.

Genomic DNA was extracted and purified by using a commercial genomic DNA extraction kit (Bioneer) and the nearly complete 16S rRNA gene sequence was amplified using bacterial universal primers (Weisburg et al., 1991). Sequencing of the $16 \mathrm{~S}$ rRNA gene of strain $\mathrm{GJ} 16^{\mathrm{T}}$ was carried out as described previously (Lane, 1991). The resulting 16S rRNA gene sequence was compared with $16 \mathrm{~S}$ rRNA gene sequences available in GenBank using the BLAST program (http://www.ncbi.nlm.nih.gov/blast/) to determine the approximate phylogenetic affiliation and using CLUSTAL W software (Thompson et al., 1994) to align the sequences of closely related organisms. Sequence similarity values were computed using Similarity Matrix version 1.1 (Ribosomal Database Project II; http://rdp.cme.msu.edu/ index.jsp; Cole et al., 2003) and the EzTaxon server (http:// www.eztaxon.org/; Chun et al., 2007). Gaps at the 5' and 3' ends of the alignment were omitted for further analyses. Phylogenetic trees were reconstructed by using the neighbour-joining and maximum-parsimony algorithms in the MEGA4.0 program (Tamura et al., 2007), with bootstrap values based on 1000 replications (Felsenstein, 1985). Evolutionary distance matrices were calculated according to the algorithm of the Kimura two-parameter model (Kimura, 1983). 
Strain $\mathrm{GJ} 16^{\mathrm{T}}$ formed a clade with the type strains of Leptobacterium flavescens (Mitra et al., 2009) and Zhouia amylolytica (Liu et al., 2006) with levels of 16S rRNA gene sequence similarity of 91.2 and $90.4 \%$, respectively (Fig. 1). Strain GJ $16^{\mathrm{T}}$ also showed significant $16 \mathrm{~S}$ rRNA gene sequence similarity to members of the genera Winogradskyella (Lau et al., 2005; 90.1-91.1\%), Dokdonia (Yoon et al., 2005; $91.1 \%$ ) and Krokinobacter (Khan et al., 2006; 90.8\%). The three algorithms used for reconstruction of the phylogenetic trees generated the same branching of the LeptobacteriumZhouia clade to which strain GJ16 ${ }^{\mathrm{T}}$ was affiliated with high bootstrap values. These data suggest that $\mathrm{GJ} 16^{\mathrm{T}}$ represents a member of a new genus within the family Flavobacteriaceae.

The following tests were performed on strains $\mathrm{GJ} 16^{\mathrm{T}}, L$. flavescens KCTC $22160^{\mathrm{T}}$ and Z. amylolytica JCM $14016^{\mathrm{T}}$. Cells grown aerobically on MA at $30{ }^{\circ} \mathrm{C}$ for 5 days were used for the examination of colony morphology, size and colour. Cell morphology and size were examined by light (FDX-35; Nikon) and transmission electron (JEM-1010; JEOL) microscopy using cells from exponentially growing cultures. The optimal temperature and temperature range for growth were tested on MA at 4, 10, 15, 20, 25, 30, 35, 37 and $42{ }^{\circ} \mathrm{C} . \mathrm{NaCl}$ requirements and tolerance were determined in the presence of $0,2,4,6,8$ and $10 \%(\mathrm{w} / \mathrm{v}) \mathrm{NaCl}$ on laboratory-prepared ZoBell agar [5 g Bacto peptone, $1 \mathrm{~g}$ yeast extract, $0.1 \mathrm{~g}$ ferric citrate and $15 \mathrm{~g}$ Bacto agar (ZoBell, 1941) in 11 modified artificial seawater containing $0-10 \%(\mathrm{w} / \mathrm{v}) \mathrm{NaCl}, 5.94 \mathrm{~g} \mathrm{MgSO}_{4} \cdot 7 \mathrm{H}_{2} \mathrm{O}$, $4.53 \mathrm{~g} \mathrm{MgCl}_{2} \cdot 6 \mathrm{H}_{2} \mathrm{O}, 0.64 \mathrm{~g} \mathrm{KCl}$ and $1.3 \mathrm{~g} \mathrm{CaCl}_{2}$. The
$\mathrm{pH}$ range for growth was determined in MB 2216 (Difco) adjusted to $\mathrm{pH} 4.0-11.0$ (at intervals of $0.5 \mathrm{pH}$ unit) with $\mathrm{HCl}$ or $\mathrm{NaOH}$ after sterilization. The Gram reaction was determined by using the bioMérieux Gram stain kit according to the manufacturer's instructions. Gliding motility was investigated using phase-contrast light microscopy by the hanging drop method as described by Bernardet et al. (2002). Anaerobic growth was tested on MA incubated for up to 15 days in the AnaeroPak-Anaero system (Mitsubishi Gas Chemical). Catalase and oxidase activities were assessed using standard methods (Tindall et al., 2007). Degradation of agar, DNA, starch and carboxymethyl-cellulose were assessed according to the methods of Smibert \& Krieg (1994). Casein hydrolysis was assessed according to the method of Norris et al. (1985); hydrolysis of chitin and Tweens 20, 40, 60 and 80 was assessed according to Baumann \& Baumann (1981). To detect flexirubin-type pigments, cell mass of the three strains was subjected to the $\mathrm{KOH}$ test as described by Bernardet et al. (2002). Antibiotic sensitivity was assessed after 3 days incubation at $30{ }^{\circ} \mathrm{C}$ on MA by the disc diffusion method and the following commercial antibiotic-impregnated discs (BBL Becton Dickson): ampicillin $(10 \mu \mathrm{g})$, gentamicin $(10 \mu \mathrm{g})$, kanamycin $(30 \mu \mathrm{g})$, neomycin $(30 \mu \mathrm{g})$, penicillin (10 IU), polymyxin $\mathrm{B}(300 \mu \mathrm{g})$, streptomycin $(10 \mu \mathrm{g})$ and tetracycline $(30 \mu \mathrm{g})$. The results were interpreted according to the guidelines set forth by the Clinical and Laboratory Standards Institute (CLSI, 2003). Other phenotypic and enzymic characterizations of strain $\mathrm{GJ} 16^{\mathrm{T}}$ and the two reference strains were conducted using API 20E, API 20NE and API

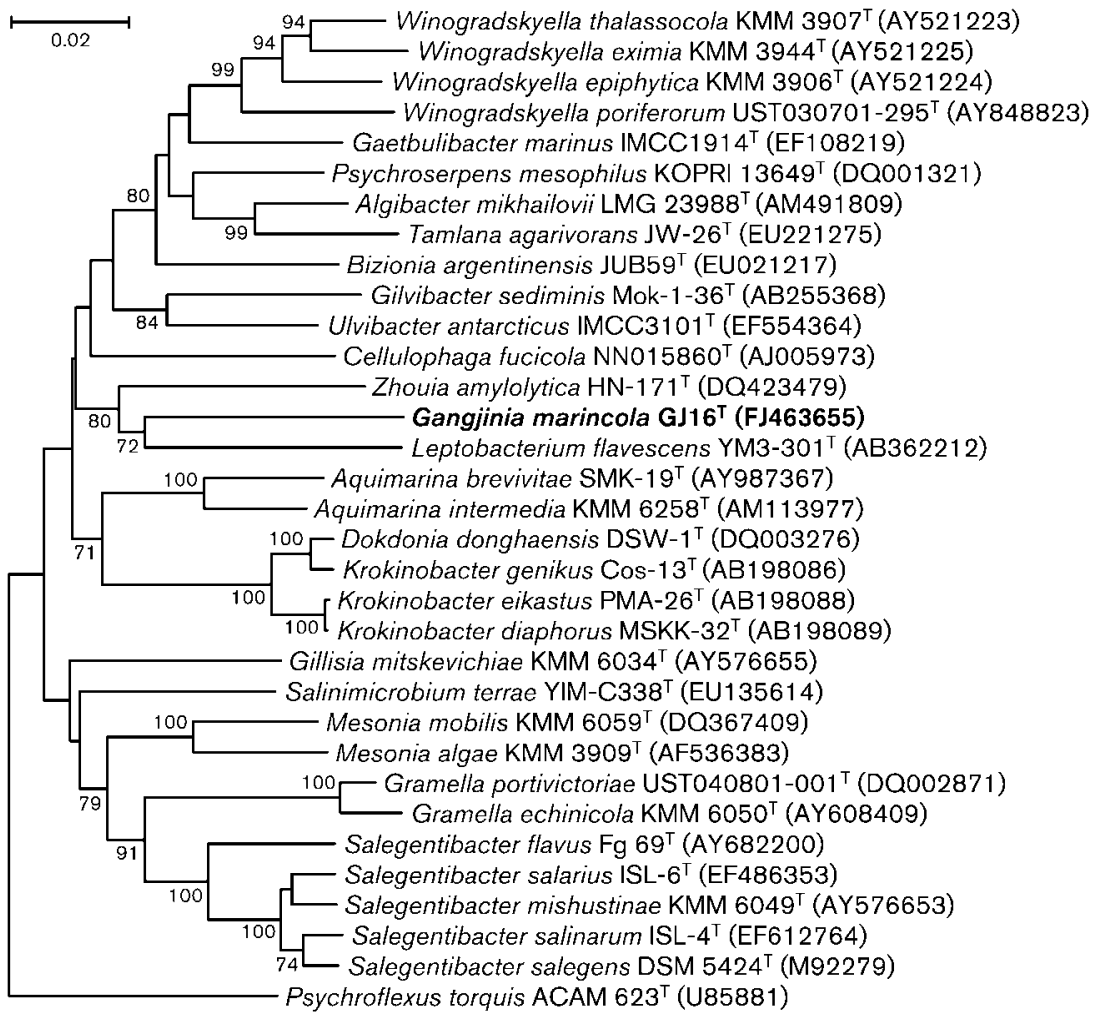

Fig. 1. Neighbour-joining phylogenetic tree based on 16S rRNA gene sequences showing the relationships of strain GJ16 ${ }^{\top}$ and representative members of the marine clade of the family Flavobacteriaceae. Bootstrap percentages (based on 1000 replicates) greater than $70 \%$ are shown at branch points. Bacteroides fragilis ATCC $25285^{\top}$ (accession no. X83935) was used as an outgroup (not shown). Bar, 0.02 substitutions per nucleotide position. 
$50 \mathrm{CH}$ kits (bioMérieux) incubated at $30{ }^{\circ} \mathrm{C}$ for 3 days and API ZYM kits incubated at $30{ }^{\circ} \mathrm{C}$ for $8 \mathrm{~h}$. The utilization of different carbon sources was tested with GN2 MicroPlates (Biolog) according to the manufacturer's instructions. All commercial kits were inoculated with bacterial suspensions in 3\% sea salts. Detailed results of morphological, physiological and biochemical tests are given in the genus and species descriptions and in Table 1.

Pigments were extracted from cells of strain GJ16 ${ }^{\mathrm{T}}$ grown in the dark in $\mathrm{MB}$ using acetone/methanol $(1: 1, \mathrm{v} / \mathrm{v})$. Cellular residues were removed by centrifugation. An adsorption spectrum $(200-800 \mathrm{~nm})$ was obtained from the crude cell extract using a Beckman Coulter DU 800 UV/ visible spectrophotometer (Varian).

The whole-cell fatty acid compositions of strain GJ16 ${ }^{\mathrm{T}}, L$. flavescens KCTC $22160^{\mathrm{T}}$ and Z. amylolytica JCM $14016^{\mathrm{T}}$ were analysed according to the instructions of the Microbial Identification System (MIDI; Microbial ID) using cells grown on MA at $30{ }^{\circ} \mathrm{C}$ for 3 days. The major respiratory quinones of strain $\mathrm{GJ} 16^{\mathrm{T}}$ were analysed by the Korean Culture Center of Microorganisms (KCCM, Seoul, Republic of Korea) using reverse-phase HPLC (Komagata \& Suzuki, 1987). The G $+\mathrm{C}$ content of the DNA of strain GJ16 ${ }^{\mathrm{T}}$ was determined using the thermal denaturation method (Marmur \& Doty, 1962) using an Ultrospec 2100 spectrophotometer (Pharmacia Biotech) and DNA from Escherichia coli $\mathrm{K}-12$ as a control.

The major cellular fatty acids of strain $\mathrm{GJ} 16^{\mathrm{T}}$ were iso$\mathrm{C}_{15: 0}(40.2 \%)$, iso- $\mathrm{C}_{15: 1} \mathrm{G}(12.8 \%)$, iso- $\mathrm{C}_{17: 0} 3-\mathrm{OH}$ $(11.2 \%)$ and $\mathrm{C}_{15: 0}(6.6 \%)$. The detailed fatty acid compositions of the three strains are compared in Table 2. Although the three strains grown under the same conditions shared similar overall fatty acid compositions, strain GJ16 $16^{\mathrm{T}}$ differed from the two reference strains by a significantly higher proportion of iso- $\mathrm{C}_{15: 0}$. The major respiratory quinone of strain $\mathrm{GJ} 16^{\mathrm{T}}$ was menaquinone 6 (MK-6), which is in line with $L$. flavescens KCTC $22160^{\mathrm{T}}$

Table 1. Phenotypic characteristics that differentiate strain $\mathrm{GJ} 16^{\top}$ from the type species of related genera

Strains: $1, \mathrm{GJ} 16^{\mathrm{T}} ; 2$, Leptobacterium flavescens KCTC $22160^{\mathrm{T}} ; 3$, Zhouia amylolytica JCM $14016^{\mathrm{T}}$. +, Positive; - , negative; w, weakly positive. All data are from this study except where marked.

\begin{tabular}{|c|c|c|c|}
\hline Characteristic & 1 & 2 & 3 \\
\hline Colony pigmentation on MA & Orange & Pale yellow & Yellow \\
\hline Salinity range for growth $(\mathrm{NaCl}, \%)$ & $2-4$ & $1-4$ & $1-7$ \\
\hline Temperature range for growth $\left({ }^{\circ} \mathrm{C}\right)$ & $25-30$ & $15-30$ & $10-40$ \\
\hline $\mathrm{pH}$ range for growth & $6-9$ & $6-9$ & $6-8$ \\
\hline \multicolumn{4}{|l|}{ Hydrolysis of: } \\
\hline Casein & + & - & - \\
\hline Gelatin & - & + & + \\
\hline Starch & + & - & - \\
\hline Tween 80 & - & + & + \\
\hline \multicolumn{4}{|l|}{ Utilization of (GN2 MicroPlate): } \\
\hline D-Galactose & - & - & + \\
\hline D-Glucose & - & - & + \\
\hline D-Mannose & - & - & + \\
\hline Melibiose & + & - & + \\
\hline Raffinose & + & - & + \\
\hline L-Rhamnose & + & - & - \\
\hline \multicolumn{4}{|c|}{ Aerobic acid production from (API $50 \mathrm{CH}$ ): } \\
\hline D-Arabinose & - & + & - \\
\hline Cellobiose & - & + & + \\
\hline Gentiobiose & - & + & - \\
\hline Maltose & - & + & + \\
\hline \multicolumn{4}{|l|}{ Enzyme activity (API ZYM) } \\
\hline Esterase (C4) & - & + & - \\
\hline Esterase lipase (C8) & - & + & $\mathrm{w}$ \\
\hline Trypsin & - & + & - \\
\hline$\alpha$-Chymotrypsin & - & + & - \\
\hline$\beta$-Glucosidase & + & - & - \\
\hline DNA G $+C$ content $(\mathrm{mol} \%)$ & 39.4 & $42.0^{*}$ & $34.5 \dagger$ \\
\hline
\end{tabular}

${ }^{\star}$ Data from Mitra et al. (2009).

$\dagger$ Data from Liu et al. (2006). 
Table 2. Fatty acid composition (\%) of strain $\mathrm{GJ} 16^{\top}$ and the type species of related genera

Taxa: 1, strain GJ16 ${ }^{\mathrm{T}}$; 2, Leptobacterium flavescens $\mathrm{KCTC} 22160^{\mathrm{T}}$; 3 , Zhouia amylolytica JCM $14016^{\mathrm{T}}$. Fatty acids amounting to less than $1.0 \%$ in all strains tested are not listed. $\operatorname{tr}$, Trace $(<1.0 \%) ;-$, not detected; ECL, equivalent chain-length. All data are from this study.

\begin{tabular}{|c|c|c|c|}
\hline Fatty acid & 1 & 2 & 3 \\
\hline \multicolumn{4}{|l|}{ Straight-chain } \\
\hline $\mathrm{C}_{15: 0}$ & 6.6 & 6.9 & 3.5 \\
\hline $\mathrm{C}_{16: 0}$ & $\operatorname{tr}$ & 2.9 & 1.2 \\
\hline \multicolumn{4}{|l|}{ Branched } \\
\hline iso- $\mathrm{C}_{14: 0}$ & 1.2 & - & - \\
\hline iso- $\mathrm{C}_{15: 0}$ & 40.2 & 27.4 & 31.3 \\
\hline iso- $\mathrm{C}_{16: 0}$ & 2.2 & 1.8 & 1.3 \\
\hline iso- $\mathrm{C}_{17: 0}$ & $\operatorname{tr}$ & 1.3 & $\operatorname{tr}$ \\
\hline anteiso- $\mathrm{C}_{15: 0}$ & 3.7 & $\operatorname{tr}$ & 1.6 \\
\hline iso- $\mathrm{C}_{15: 1} \mathrm{G}$ & 12.8 & 15.5 & 17.6 \\
\hline iso- $\mathrm{C}_{16: 1}$ & 1.5 & $\operatorname{tr}$ & $\operatorname{tr}$ \\
\hline iso- $\mathrm{C}_{17: 1} \omega 9 c$ & 2.2 & - & $\operatorname{tr}$ \\
\hline \multicolumn{4}{|l|}{ Unsaturated } \\
\hline $\mathrm{C}_{15: 1} \omega 6 c$ & 1.3 & - & - \\
\hline \multicolumn{4}{|l|}{ Hydroxy } \\
\hline $\mathrm{C}_{15: 0} 3-\mathrm{OH}$ & $\operatorname{tr}$ & 1.0 & $\operatorname{tr}$ \\
\hline iso- $\mathrm{C}_{15: 0} 3-\mathrm{OH}$ & 4.4 & 6.6 & 7.0 \\
\hline $\mathrm{C}_{16: 0} 3-\mathrm{OH}$ & $\operatorname{tr}$ & 3.4 & $\operatorname{tr}$ \\
\hline iso- $\mathrm{C}_{16: 0} 3-\mathrm{OH}$ & 1.5 & $\operatorname{tr}$ & $\operatorname{tr}$ \\
\hline $\mathrm{C}_{17: 0} 3-\mathrm{OH}$ & $\operatorname{tr}$ & 1.9 & $\operatorname{tr}$ \\
\hline iso- $\mathrm{C}_{17: 0} 3-\mathrm{OH}$ & 11.2 & 14.6 & 15.1 \\
\hline Summed feature $3^{*}$ & 1.1 & 3.0 & 6.5 \\
\hline ECL 13.565 & 3.3 & 6.9 & 6.6 \\
\hline
\end{tabular}

* Summed features represent groups of two or three fatty acids that cannot be separated by GLC with the MIDI system. Summed feature 3 contained iso- $\mathrm{C}_{15: 0} 2-\mathrm{OH}$ and/or $\mathrm{C}_{16: 1} \omega 7 c$.

(Mitra et al., 2009) and Z. amylolytica JCM $14016^{\mathrm{T}}$ (Liu et al., 2006) and all other members of the family Flavobacteriaceae. Flexirubin-type pigments were not produced by any of the three strains. Cells of strain $\mathrm{GJ} 16^{\mathrm{T}}$ produced orange-coloured carotenoid-type pigments with absorption peaks at $451 \mathrm{~nm}, 474 \mathrm{~nm}$ (major peak) and $503 \mathrm{~nm}$ (Schmidt et al., 1994). The G $+\mathrm{C}$ content of the genomic DNA of strain GJ16 $6^{\mathrm{T}}$ was $39.4 \mathrm{~mol} \%$, a value between those reported for the two reference strains (Mitra et al., 2009; Liu et al., 2006).

In conclusion, on the basis of phylogenetic analysis and differential phenotypic properties, strain $\mathrm{GJ} 16^{\mathrm{T}}$ represents a novel species in a new genus in the family Flavobacteriaceae, for which the name Gangjinia marincola gen. nov., sp. nov. is proposed.

\section{Description of Gangjinia gen. nov.}

Gangjinia (Gang.ji'ni.a. N.L. fem. n. Gangjinia named after Gangjin Bay, located on the South Sea in Korea, from where the organism was isolated).
Cells are strictly aerobic, Gram-stain-negative, orangepigmented, non-flagellated and rod-shaped (Supplementary Fig. S1, available in IJSEM Online). Gliding motility is absent. Oxidase and catalase activities are present. Nondiffusible carotenoid-type pigments are produced, but flexirubin pigments are absent. The major respiratory quinone is MK-6. The cellular fatty acid composition is dominated by iso- $\mathrm{C}_{15: 0}$, iso- $\mathrm{C}_{15: 1} \mathrm{G}$, iso- $\mathrm{C}_{17: 0} 3-\mathrm{OH}$ and $\mathrm{C}_{15: 0}$. The genus is a member of the family Flavobacteriaceae, phylum 'Bacteroidetes'. The type species is Gangjinia marincola.

\section{Description of Gangjinia marincola sp. nov.}

Gangjinia marincola (ma.rin.co'la. L. n. mare the sea; L. n. incola inhabitant; N.L. n. marincola inhabitant of the sea).

Displays the following characteristics in addition to those given in the genus description. Colonies on MA are orange in colour, circular, 1.0-3.0 $\mathrm{mm}$ in diameter and convex with smooth surfaces and entire margins. Non-diffusible carotenoid-type pigments with absorption peaks at $451 \mathrm{~nm}$, $474 \mathrm{~nm}$ and $503 \mathrm{~nm}$ are produced. Growth occurs at 20$30{ }^{\circ} \mathrm{C}$ (optimum at $25-30{ }^{\circ} \mathrm{C}$ ), at $\mathrm{pH} 6.0-9.0$ (optimum at $\mathrm{pH} 7.0-8.0$ ) and with $2-4 \% \mathrm{NaCl}$ (optimum in $3 \% \mathrm{NaCl}$ ). However, no growth is observed at $15{ }^{\circ} \mathrm{C}$ or $30{ }^{\circ} \mathrm{C}$, at pH 5.5 or 9.5 , or in the presence of $<1 \%$ or $>5 \% \mathrm{NaCl}$. Anaerobic growth does not occur on marine agar. Acetoin, indole and $\mathrm{H}_{2} \mathrm{~S}$ are not produced. Nitrate is not reduced. Hydrolyses casein, starch and DNA, but not agar, carboxymethylcellulose, chitin or Tween compounds. Arginine dihydrolase, lysine decarboxylase, ornithine decarboxylase, tryptophan deaminase and urease activities are absent. In the API ZYM kit, alkaline phosphatase, leucine arylamidase, valine arylamidase, acid phosphatase, naphthol-AS-BIphosphohydrolase, $\alpha$-glucosidase and $N$-acetyl- $\beta$-glucosaminidase activities are present, but esterase (C4), esterase lipase (C8), lipase (C14), cystine arylamidase, trypsin, $\alpha$-chymotrypsin, $\alpha$-galactosidase, $\beta$-galactosidase, $\beta$-glucuronidase, $\beta$-glucosidase, $\alpha$-mannosidase and $\alpha$-fucosidase activities are absent. In the API $50 \mathrm{CH}$ kit, acid is only produced aerobically from aesculin-ferric citrate and 5ketogluconate. In the GN2 MicroPlate, the following substrates are utilized as sole carbon sources: melibiose, raffinose, L-rhamnose, methyl pyruvate, $\alpha$-ketoglutaric acid, $\alpha$-ketovaleric acid, propionic acid, L-alanyl glycine, L-glutamic acid, L-leucine, L-ornithine, L-phenylalanine, thymidine, putrescine, $\alpha$-cyclodextrin, dextrin, glycogen, acetic acid, $\gamma$-hydroxybutyric acid, glucuronamide, L-alanine, glycyl L-glutamic acid, L-proline and phenylethylamine. None of the other carbon sources in the GN2 Microplate are utilized. Resistant to kanamycin $(30 \mu \mathrm{g})$, gentamicin $(10 \mu \mathrm{g})$, neomycin $(30 \mu \mathrm{g})$ and polymyxin $\mathrm{B}(300 \mu \mathrm{g})$, but sensitive to ampicillin $(10 \mu \mathrm{g})$, penicillin (10 IU), streptomycin $(10 \mu \mathrm{g})$ and tetracycline $(30 \mu \mathrm{g})$.

The type strain is $\mathrm{GJ} 16^{\mathrm{T}}\left(=\mathrm{KCTC} 22649^{\mathrm{T}}=\mathrm{JCM} 16082^{\mathrm{T}}\right)$, isolated from coastal seawater of Gangjin Bay, the southernmost part of the Korean peninsula. The DNA $\mathrm{G}+\mathrm{C}$ content of the type strain is $39.4 \mathrm{~mol} \%$. 


\section{Acknowledgements}

This research was supported by the Ministry of Environment (grant no. 2008-05001-0033-0).

\section{References}

Baumann, P. \& Baumann, L. (1981). The marine gram-negative eubacteria: genera Photobacterium, Beneckea, Alteromonas, Pseudomonas, and Alcaligenes. In The Prokaryotes, vol. 1, pp. 13021331. Edited by M. P. Starr, H. Stolp, H. G. Trüper, A. Balows \& H. Schlegel. Berlin: Springer.

Bernardet, J.-F. \& Nakagawa, Y. (2006). An introduction to the family Flavobacteriaceae. In The Prokaryotes, a Handbook on the Biology of Bacteria, 3rd edn, vol. 7, pp. 455-480. Edited by M. Dworkin, S. Falkow, E. Rosenberg, K. H. Schleifer \& E. Stackebrandt. New York: Springer.

Bernardet, J.-F., Nakagawa, Y. \& Holmes, B. (2002). Proposed minimal standards for describing new taxa of the family Flavobacteriaceae and emended description of the family. Int J Syst Evol Microbiol 52, 1049-1070.

Bowman, J. P. (2006). The marine clade of the family Flavobacteriaceae: the genera Aequorivita, Arenibacter, Cellulophaga, Croceibacter, Formosa, Gelidibacter, Gillisia, Maribacter, Mesonia, Muricauda, Polaribacter, Psychroflexus, Psychroserpens, Robiginitalea, Salegentibacter, Tenacibaculum, Ulvibacter, Vitellibacter and Zobellia. In The Prokaryotes, a Handbook on the Biology of Bacteria, 3rd edn, vol. 7, pp. 677-694. Edited by M. Dworkin, S. Falkow, E. Rosenberg, K. H. Schleifer \& E. Stackebrandt. New York: Springer.

Chun, J., Lee, J. H., Jung, Y. Y., Kim, M. J., Kim, S. I., Kim, B. K. \& Lim, Y. W. (2007). EzTaxon: a web-based tool for the identification of prokaryotes based on 16S ribosomal RNA gene sequences. Int J Syst Evol Microbiol 57, 2259-2261.

CLSI (2003). Performance standards for antimicrobial disk and dilution susceptibility tests for bacteria isolated from animals, 2nd edn. Approved standard M31-A2. Wayne, PA: Clinical and Laboratory Standards Institute.

Cole, J. R., Chai, B., Marsh, T. L., Farris, R. J., Wang, Q., Kulam, S. A., Chandra, S., McGarrell, D. M., Schmidt, T. M. \& other authors (2003). The Ribosomal Database Project (RDP-II): previewing a new autoaligner that allows regular updates and the new prokaryotic taxonomy. Nucleic Acids Res 31, 442-443.

Felsenstein, J. (1985). Confidence limit on phylogenies: an approach using the bootstrap. Evolution 39, 783-791.

Khan, S. T., Nakagawa, Y. \& Harayama, S. (2006). Krokinobacter gen. nov., with three novel species, in the family Flavobacteriaceae. Int $J$ Syst Evol Microbiol 56, 323-328.

Kimura, M. (1983). The Neutral Theory of Molecular Evolution. Cambridge: Cambridge University Press.

Komagata, K. \& Suzuki, K. (1987). Lipid and cell-wall analysis in bacterial systematics. Methods Microbiol 19, 161-207.
Lane, D. J. (1991). 16S/23S rRNA sequencing. In Nucleic Acid Techniques in Bacterial Systematics, pp. 115-175. Edited by E. Stackebrandt \& M. Goodfellow. Chichester: Wiley.

Lau, S. C. K., Tsoi, M. M. Y., Li, X., Plakhotnikova, I., Dobretsov, S., Lau, K. W. K., Wu, M., Wong, P.-K., Pawlik, J. P. \& Qian, P.-Y. (2005). Winogradskyella poriferorum sp. nov., a novel member of the family Flavobacteriaceae isolated from a sponge in the Bahamas. Int J Syst Evol Microbiol 55, 1589-1592.

Liu, Z.-P., Wang, B.-J., Dai, X., Liu, X.-Y. \& Liu, S.-J. (2006). Zhouia amylolytica gen. nov., sp. nov., a novel member of the family Flavobacteriaceae isolated from sediment of the South China Sea. Int J Syst Evol Microbiol 56, 2825-2829.

Marmur, J. \& Doty, P. (1962). Determination of the base composition of deoxyribonucleic acid from its thermal denaturation temperature. J Mol Biol 5, 109-118.

Mitra, S., Matsuo, Y., Haga, T., Yasumoto-Hirose, M., Yoon, J., Kasai, H. \& Yokota, A. (2009). Leptobacterium flavescens gen. nov., sp. nov., a marine member of the family Flavobacteriaceae, isolated from marine sponge and seawater. Int J Syst Evol Microbiol 59, 207-212.

Norris, J. R., Ribbons, D. W. \& Varma, A. K. (editors) (1985). Methods in Microbiology, vol. 18. London: Academic Press.

Schmidt, K., Connor, A. \& Britton, G. (1994). Analysis of pigments: carotenoids and related polyenes. In Chemical Methods in Prokaryotic Systematics, pp. 403-461. Edited by M. Goodfellow \& A. G. O'Donnell. Chichester: Wiley.

Smibert, R. M. \& Krieg, N. R. (1994). Phenotypic characteristics. In Methods for General and Molecular Biology, pp. 607-654. Edited by P. Gerhardt, R. G. E. Murray, W. A. Wood \& N. R. Krieg. Washington, DC: American Society for Microbiology.

Tamura, K., Dudley, J., Nei, M. \& Kumar, S. (2007). MEGA4: molecular evolutionary genetics analysis (MEGA) software version 4.0. Mol Biol Evol 24, 1596-1599.

Thompson, J. D., Higgins, D. G. \& Gibson, T. J. (1994). CLUSTAL W: improving the sensitivity of progressive multiple sequence alignment through sequence weighting, position-specific gap penalties and weight matrix choice. Nucleic Acids Res 22, 4673-4680.

Tindall, B. J., Sikorski, J., Smibert, R. A. \& Kreig, N. R. (2007). Phenotypic characterization and principles of comparative systematics. In Methods for General and Molecular Microbiology, pp. 330-393. Edited by C. A. Reddy, T. J. Beveridge, J. A. Breznak, G. A. Marzluf, T. M. Schmidt \& L. R. Snyder. Washington, DC: American Society for Microbiology.

Weisburg, W. G., Barns, S. M., Pelletier, D. A. \& Lane, D. J. (1991). 16S ribosomal DNA amplification for phylogenetic study. J Bacteriol 173, 697-703.

Yoon, J.-H., Kang, S.-J., Lee, C.-H. \& Oh, T.-K. (2005). Dokdonia donghaensis gen. nov., sp. nov., isolated from sea water. Int J Syst Evol Microbiol 55, 2323-2328.

ZoBell, C. E. (1941). Studies on marine bacteria. I. The cultural requirements of heterotrophic aerobes. J Mar Res 4, 42-75. 